\title{
Making Space for What Lies in the Interstices: The Composing Practices of Single Moms
}

\author{
Alex Hanson
}

Alex Hanson is a doctoral candidate in Composition and Cultural Rhetoric at Syracuse University where her research focuses on the experiences of single moms in higher education. Her writing has appeared in Composition Studies, Xchanges, and The Journal of Multimodal Rhetorics.

$\mathrm{I}$ sit in front of my computer, trying to transcribe the last 15 minutes of an interview. At this point, I've done almost 18 hours of interview audio totaling 250 pages, and I am ready to be done. I feel so close to finishing this transcript, but I have something, or rather, someone else vying for my attention-my $51 / 2$-year-old daughter, Olivia. After she gets home from school, she wants me to play with her, to engage in her role-playing game in which she will reenact what happened that day. "Just let me finish this transcript, and then I'll be happy to play with you," I tell her, while also encouraging her to do whatever she wants until I am done. Instead of going off to do her own thing, she climbs under the dining table and into my lap, listening to the audio and quickly picking up on how my Esc key is my Play and Pause button. She is wiggly, anxious, and to her, 5 minutes feels like an eternity. I know this transcription will take at least 30 .

Her little pointer finger lingers above the Esc key as I type, as she integrates herself into the workflow. "Go ahead and push it," I say, as I get to a point at which I need to pause the audio. She does, and after doing this a few times, starts to feel courageous. She reaches for a letter key, a $t$ and then a $p$ before I tell her to stop. She begins to slump down, arms crossed, and then whispers in my ear, "Can I tell you a secret?"

"Of course," I say.

"Are you mad at me?"

"No, honey. I'm not mad at you. This transcript has just taken me all day to do, and I wouldn't want you to accidentally undo all of that work by pressing the wrong key, that's all. I'm not mad at you. I love you." I hug her and then ask her if she'll go back to being my assistant, to pushing the Esc key for me. She does. And after half an hour of this, of her and me pushing keys, of her asking questions about the voice coming from my computer, of her trying to match the words from that voice with the words on my computer screen, we finish and move away from the computer and into the world of her kindergarten classroom where she had a substitute teacher for the day who made promises of s'mores for snacks and candy math games.

This is a snapshot of my composition life, a glimpse into a world where, even as I desperately try to finish all my writing when my daughter is gone, I still continually fall

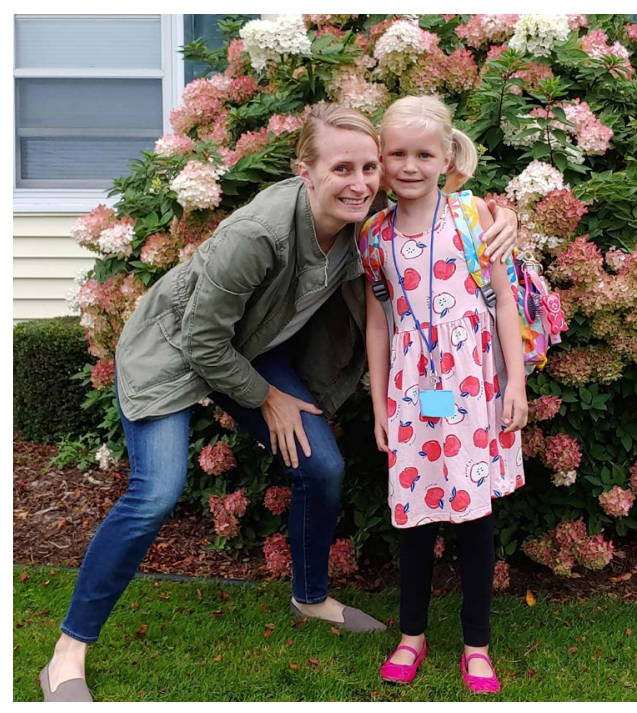

\begin{abstract}
"Making Space..." asks readers to consider how we can broaden our understanding of what counts as composition practice and work when we make space for the composition experiences of those with marginalized identities, specifically single moms. Using testimonios to share the composition practices of single moms in higher education, the author shares how the composition process of single moms is one of improvisation, of finding a way to make space for composition work, and of pushing boundaries of what a composing process looks like and what it means.
\end{abstract}

\section{Keywords}

composition practice, process, single mothers, testimonios 
short of my goal. She is an only child. Her dad and I are divorced. Livy and I have been doing this work-life dance for the past three years, one in which she is the Esc key to my composing, in which her absence and presence determine how, when, and where I write, or if I do at all. My experience reflects the composition practices of other single moms across disciplines, academic ranks, and geographic locations. In an interview with Art Lit Lab, Kate Vieira describes how her identity as a single parent shapes the way she completes her writing, how she writes first thing in the morning but tries not to work "in the evenings or on the weekends" because that is precious time with her daughter, time for the two of them to "irritate the bejeesus out of each other." She acknowledges that in the moments when she does need to write and her daughter is there, writing time is limited-"Sometimes I have 30 minutes. Sometimes it's a couple hours. It's sacred." Vieira's perspective offers an initial glimpse into what the composing experience of a single parent is like.

Within composition and rhetoric, we don't often see into the writing experiences of people with marginalized identities. While there was substantial scholarship on the process movement from 1976 to 1995, as Pamela Takayoshi points out, conversations around the topic have fallen into a lull since, with occasional process studies scholarship coming to the surface, like that of Paul Prior and Jody Shipka, Theresa Lillis, and most recently, Christine Tulley. Such work explores academic writers' composition practices-how those writers get work done. Oftentimes, these studies involve interviews with students or writing scholars, who talk about the strategies and methods they implement throughout their composition process (see Rogers). Occasionally, such studies also involve longitudinal work that follows student writers, or other methods, like asking participants to create visual representations of their writing processes (see Prior and Shipka). Within this work, one "interstitial gap"- -the unheard, unthought, the unspoken"-is evidenced through the absence of single parents, and more specifically, single mothers (Pérez 5). Tulley acknowledges that looking at how gender affects writing within rhetoric and composition "is essential" (153). Her emphasis on this need comes from not only an absence of attention to the topic but also the relationship between gender and parenting and how women are often disproportionately impacted in their writing "due to the birth of children ${ }^{1 \text { " }}$ (153). While single parents as a whole face professional challenges related to their parental identity, this article focuses on single moms because they represent the majority of single parents in the United States and because of their marginalization ("America's Families"; Sidel 22-23). Additionally, such perspectives are important because they broaden the pool of knowledge from which teachers, administrators, and scholars can draw to make sense of writing experiences across identities, and as Pamela Takayoshi argues, "If teachers of writing are to effectively help writers learn to be effective and productive in contemporary academic and non-academic contexts, then we need to know what composing demands writers must negotiate" (573). The composing demands of single parents call for a feminist understanding of composition practice, one that takes into consideration how lived experience, material reality, and the personal shape what composition practice looks like in and out of the classroom.

Tricia, Julie, and Danielle ${ }^{2}$ are three single moms whose composition practices indicate the value of paying attention to what is often unseen and beyond our control as writers. What follows are their stories, stories I was fortunate to learn about through interviews conducted with them over the course of a semester. While I interviewed seven single moms, I have chosen to focus on these three women because of how they represent a range of experiences-a divorced single mom PhD student on medical leave for the past year who shares custody with her son's dad, a divorced single mom working at a community college who has sole custody of her two children, and a single mom by choice completing her bachelor's degree while working full time and raising her son. Their stories push and expand our thinking about what counts as composition practice, why composition practice does not happen, and how composition practices in and out of the classroom can be valuable resources. I tell their stories using testimonios, described by the Latina Feminist Group as "a crucial means of bearing witness and inscribing into history those lived realities that would otherwise succumb to the alchemy of erasure" (2). Like the Latina Feminist Group, I see testimonios as a way for participants to bear witness to their experiences as single mothers in academia, and through the sharing of their stories, to represent not just what has happened in their personal lives but also what has happened to them as a community (13). I recognize that I take up this methodology as a white woman writing about the experiences of single mothers who may or may not identify as Latinx. In doing so, my intention is not to conflate the experiences of these two groups or the stakes of erasure that the Latina Feminist Collective describes. Instead, as a methodology, I see testimonios offering a unique, decolonial way of sharing the lived experiences of those who have been marginalized. It is a methodology that allows single moms' stories to be part of a collective, rather than functioning as individual, separate narratives. This collectivity reveals how the challenges of single moms are communal not individualistic, strengthening the need to support these women as a group.

1 Tulley also emphasizes the need to consider how race "affects writing within rhetoric and composition" and acknowledges that women are disproportionately impacted as a result of "caring for aging parents" as well (153).

2 The information these women shared was part of an IRB approved study. To adhere to the IRB requirements, participants' names and other identifying details have been changed to maintain their anonymity. To ensure that the participants were comfortable with how they were represented, I provided each one with a draft of this article before I submitted it to WCC for consideration. They all okayed it, suggesting two minor changes (one related to the number of students enrolled in a class, and another related to the use of blogs). 
I have chosen to write these women's stories from their perspectives, using data from our interview conversations to weave together their narratives. In this way, my intention is to honor their stories as told by them, and as Jillian Duquaine-Watson writes in her own research about single mothers, to "promote increased attention to the specific ways participants construct their narratives, including the specific discourses they use to describe their lives and experiences" (41). Intertwined with their narratives is my analytical perspective of their stories. To make clear where their voices occur in the text, I block quote their words. I also use subheaders to indicate when a new single mom's story occurs.

\section{TRICIA'S STORY}

When I talked with Tricia, many things struck me in our conversation. Her passion for her research, which focuses on a wearable medical device that centers mental healthcare, is evident in how she finds ways to bring it into the discussion even when you might not be expecting it. Her academic interests are broad-she majored in bioengineering, minored in writing and rhetoric, and is currently pursuing a $\mathrm{PhD}$ in information science and technology. She's a single mom with shared custody, an academic, and an army veteran who completed a tour in Iraq. But what struck me most about Tricia is her resourcefulness and her resilience. For example, when Tricia first started college, she was commuting two hours one way. After she dropped her son off at daycare, she would go to work, glancing at cheat sheets for exams during her drive, and she created her own audiobooks by recording herself reading chapters and playing them back on the trip. As she told me, "I imagine Homer Simpson in his car with his toaster and everything; as a single parent, you're trying to create this multitool where you're able to do all of these wonderful things at once and change the baby's diaper." Similarly, when Tricia went on medical leave shortly into her PhD program, she found alternative ways to complete her academic work as she dealt with photophobia and screen intolerance. Tricia's resourcefulness and resilience are informed in part by her identity as a single mother, which has required her to find ways to get work done, even when that feels impossible.

When Tricia became a single parent three years into her bachelor's degree, she began to feel the strain of her parental identity, which she compared to "having two full-time jobs without a day off. It's just work, work, work all the time." As she struggled to keep up with her schoolwork, she became increasingly aware of how her experience as a single mom shaped her approach to academic work.

It was all I could do to keep up with my schoolwork, much less research on top of it. I don't have time to be the rock star supermom that I want to be and be concerned about how my child is developing and growing. You have to cut some corners. Rather than focusing on my studies and getting straight As, I'm okay with having a B and having an extra four hours of my time every week. When you're in academia, always in the back of your mind you're focusing on what you have to do. You can never really shut that off completely and focus on other things when you're supposed to be performing those roles. I've been on medical leave for almost two years, and I still have that anxiety related to academic roles.

Even with "cutting corners," Tricia has found a way to maintain a presence in her various roles: as a veteran, she goes to veterans' social events; as an undergrad, she regularly completed her academic projects, had a strong presence in her research labs, and received multiple university-wide awards for her work; as a single mom, she supported her son as he learned to play an instrument and supports him now as he participates in martial arts. Despite this involvement, her presence is not without sacrifices. She has had to adjust the expectations she has for herself as a student and single mom so she can do the work of both. Knowing about Tricia's experiences as a veteran, an academic, and a single mom are important because they make visible how Tricia has continuously found a way to perform her various roles despite the constraints she encounters. She has experience doing this kind of work, which means that when she ended up on medical leave, unable to read or write, she had a self-created blueprint for finding a way she could reference.

Tricia's two-year medical leave is the result of a two-minute interaction with her service dog. As she tells it,

I was in my bedroom with my music on, doing a happy dance, excited about going to visit a fellow researcher outside of the country during spring break, when I bent down to love on my dog, to pet her. I didn't know that I was going to hit my head on the corner of my bed, but I did. I don't really do happy dances anymore; the last one changed so much about my life.

It seems clichéd to say so much about life can change in an instant, but Tricia's experience is just that. I'm not sure how often in academia we're prepared for these moments, the ones when someone's life drastically shifts and the way they used to do things is not the way they can do them anymore. We've gotten a glimpse into that as we've tried to adjust due to the COVID 19 pandemic, and in some ways, that reveals how messy and challenging responding to a sudden shift can be. Now imagine having to make that type of adjustment on your own, with a 10-year-old child, while also adjusting to life with a disability. That has been Tricia's experience.

Now, I have photophobia and screen intolerance and some inflammation on the left side of my head. I used to read and write a lot, but since l've been on medical leave, l've been unable to. I am a writer, but I can't write. At first, I tried to 
read just to catch up on my schoolwork because I thought I was going to get better right away. I would read for like 20 minutes, and then I had to sleep for two hours directly after because it exhausted me so much. I have notebooks, I have pen and paper, but when I try to go back to read and edit them, it's painful, so I just kind of gave up. Instead, what l've been doing is painting. Paint is much easier for me. When I'm painting, the pain doesn't go away. The pain is constant. It just isn't aggravated or increased. My walls are full of paintings now, and I have lots of paintings (in acrylic) that have mostly words on them.

There are aphorisms in there, there are engineering equations, there are movements, and there are arrows. Rhetoric is one of the words that's in one of my paintings. One of my paintings says "Information." It was upside down. I flip them around because they don't really have sides, and when you flip them around, you can see different things in them. It's almost like a brain mapping, and a lot of it has to do with my research and trying to figure out a way to move forward with my thought processes. Some of it is listening to audiobooks and just me responding to them because that's what I used to do before I hit my head. I was kind of more like on autopilot listening to audiobooks, kind of wanting to take notes or at least responding and jotting stuff down that I thought was really important at the time, and then it kind of gets mixed in with reflections and different experiences.

It's really hard when you're a writer, and you hit your head, and you become disabled, and you're not able to write anymore. Writing has been my outlet since I was a teenager; I used to keep journals and diaries or whatever; that's the tool I've always used, and it was taken from me.

Tricia is not only a graduate student veteran, she is also a single mom, and as a single mom, she has developed strategies and ways of doing work that are reflected in her current practice. Just as Tricia found a way to do work during her two-hour commute, she now uses painting to process and reflect on her research and turns to audiobooks to continue reading. She is doing this on her own. When Tricia went on medical leave, she became what she termed "a ghost in the background," someone who is unacknowledged, whose only means to maintain contact with students and faculty in her academic program is through a method that causes pain. Looking at screens hurts. Fluorescent lights hurt. This pain eliminates the potential for email, text messaging, and, often, meeting in person, which meant that if Tricia wanted to continue her academic work, she was left to find a way on her own. Her experience reveals how academia can be exclusionary, and how we are all vulnerable to being excluded at any time, as well as the limitations of academia when it comes to composition. While Tricia can compose through painting, and she can talk at length about her research, she is unable to participate in her PhD program because looking at screens and reading or writing on paper is painful, despite her deeply engrained identity as a writer and academic. Tricia's experience begs the question, How might we broaden our conception of composition practice to make space for the unexpected challenges people of all subjectivities encounter? When Tricia told me about her painting experience, she also shared her painting process, which reflects the composing process she had while writing.

When I paint, I improvise. I pick a color that I feel like at the moment, and I just kind of have to fill up the canvas until it's not blank anymore, and sometimes as I'm kind of slapping paint around the canvas, something shows up or comes to my mind, like l'll picture something in the canvas, and then I'll paint that into it. I call it improvisation. Before I went on medical leave, my writing process was pretty much like what I do when I paint-I didn't necessarily have a plan, l'd just sit down and start doing it. I wrote into or through my ideas. Then, my ideas would come out in conversation, too. It always helps me to talk to different researchers and different people because that's when my random ideas will come up, and I would write them down real fast.

There needs to be space for composing practices like Tricia's in higher education, space for students who may face an unexpected change in life circumstances but find innovative ways to engage in intellectual work despite that change. Tricia's way of working is different, but that does not mean her way is any less valuable, meaningful, or beneficial to her research. Focusing on what she can do-have thoughtful, in-depth telephone conversations, express and process ideas through painting, and listen to audiobooks - is a starting point for including Tricia in academia despite the constraints of what counts and is valued in higher education. Tricia may not be in composition and rhetoric, but are there ways ideas from composition and rhetoric might be used to inform and develop a broader understanding of what it means to complete composition work in other disciplines? For example, Shipka, drawing on Kathleen Yancey's 2014 article "Looking for Sources of Coherence in a Fragmented World," describes composition as "a thing with parts-with visual-verbal or multimodal aspects-the expression of relationships and, perhaps most importantly, the result of complex, ongoing processes that are shaped by, and provide shape for, living" (17). Tricia's composition process, which is deeply influenced by her material practice, lived reality, and embodied experience, fits Shipka's definition. Her paintings are things with parts that express relationships among what she listens to, researches, and experiences.

\section{JULIE'S STORY}

Just listening to all the things Julie does had me feeling exhausted. She works at a community college where she teaches a 6/6 load, mentors new online and hybrid teachers, and coadvises a transfer partnership with a nearby $\mathrm{R} 1$. She also teaches an exercise 
class at a local YMCA and has full custody of her two children, which means coordinating multiple schedules and extracurricular activities. In addition, for six years prior to our conversations, she had worked on her $\mathrm{PhD}$ in English while continuing to work full time at the community college where she currently teaches. Her decision to pursue a doctorate while working full time was out of necessity: "Otherwise, I would have had to make a choice between finishing the PhD and feeding the kids. You just can't feed kids on a grad stipend." Given Julie's constant activity, it should come as no surprise that she is highly organized, as she explained to me:

For better or worse, I've always been really Type A. Those have only become strengths as a single parent; it's how I manage the household with the kids. I also have a [ridiculously] color-coded calendar in my phone that I use to keep track of everything; if it's not in my phone, it doesn't exist. I've always been a fairly scheduled person, but because I'm a single mom, I'm very scheduled with my composition work. When I had a functional partner in the house, I had the freedom of being able to go into work if I needed to do something, or stay up extra late to complete whatever it is I'm writing and knowing someone will be there in the morning to take care of the kids. With my dissertation, I had set writing times, but the mom guilt was overwhelming at times. In fact, part of my acknowledgments in my dissertation are a bit of an apology to my kids, like, "Thanks for being patient for all of the times I had to say, 'I'm sorry. This Saturday is mine; I cannot do anything." I was able to finish my dissertation because I got a very unexpected fellowship. It could have turned easily into, I can't do this anymore. I can't work all day and come home and take care of my kids and their needs and write all night and still be a sane functioning human being. Now, the only time I get to myself is after the kids go to bed, and the older they get, the shorter that window gets. If they're not going to bed until 9:30 or 10:00, I get maybe 30 minutes, and that can be hard. Now that I'm done with the $\mathrm{PhD}, \mathrm{I}$ have set work times, which is how I get my work here done. I also have had a very longstanding personal policy that when I go home for the day, work does not come with me. I get all of my work done while I'm at work. If it doesn't get done during my workday, it doesn't get done that day. Y'all can email me at 9:00 at night; I'm not responding. I tell my colleagues and students, "I am on campus from this to this, and so you can get responses from me in that time." But I'm not checking my email on Sunday morning. I'm not taking anything with me when I go to the beach for the day.

Julie's experience shows how writing is shaped by context. She's protective of the little time she has for herself, and she creates boundaries between her work and personal life to protect that time. Much of this is because she is a single mom. She recognizes that with a functional partner, the space and opportunities for writing are different-she could stay up late, return to work to finish something, or leave for a few hours on the weekend to work on a project. However, now that she is a single mom, these spaces and opportunities are no longer available. As a PhD student, when Julie had to write for the degree, she found time as a single mom, but that wasn't without the cost of guilt. Writing required the cooperation and understanding of her children, cooperation and understanding that was as crucial to the writing process as a keyboard and a screen. What afforded her the time, a finite resource for single parents, was something not everyone gets-a fellowship. Many academics would benefit from such an opportunity, but as a single mom, this assistance was especially precious for Julie. Her experience makes evident the importance of administrators and faculty selecting fellowship recipients based not only on merit but also on need. Otherwise, there's a higher risk of attrition.

Since Julie has completed her dissertation, her academic writing is "in a lull right now." She tried to write after the dissertation, but when she sat down, she struggled-"I was just like 'I'm still not there.' My brain is just starting to bounce back. I'm kind of in the in-between stage, coming up for air right now." Because Julie teaches at a community college, writing for scholarship is not rewarded-"I won't get a promotion or a raise or a title or anything else if I publish 15 books." For Julie, this is "the biggest hurdle" to completing writing for publication; it has no bearing on her position, income, or responsibilities as a faculty member. In some ways, her position affords her an opportunity to enjoy the time she hasn't had since 2012 when she started her doctoral program: "It's just been really nice to go home and not have writing hanging over my head. I'm trying to enjoy the time I have." In a culture where there is a constant push to be productive, to "publish or perish," Julie's perspective creates space to recognize how part of the composition process is not composing but instead taking a break to breathe, relax, and enjoy the time rather than seeing it as something to be filled with academic work. Despite not completing writing for scholarship, Julie is still engaged in a substantial amount of composition work, or what she terms "work-related writing."

Because I teach a 6/6 load, I'm constantly doing course prep, part of which includes closed captioning videos that I use. I also do some report writing and administrative writing for my work with the transfer partnership program at the nearby R1. I've been doing some revamp work for all of my classes that I teach, and I teach five potentially different classes at any given moment.

In addition to the course prep, administrative writing, and course design, Julie also does a substantial amount of written feedback, the kind that comes with a 6/6 teaching load of writing classes ranging from 22 to 25 students across academic levels and experiences. She is engaging extensively in what Barbara K. Townsend and Vicki J. Rosser term "scholarly activity" (670). This scholarly activity is evidenced through Julie's redesign of courses-her willingness to update courses she has previously taught drawing on recent knowledge she has acquired-as well as her approach to feedback on student writing, which evolves with the students 
she teaches, and her mentorship of new online instructors. Her experience encourages a reconsideration of how productivity is measured, what counts, and what is rewarded.

Even though Julie isn't producing publications right now, she knows how she works best-collaboratively and in response to CFPs. She has multiple joint projects with coauthors on "the back burner"-two are finishing their dissertations, and at the time of our conversation, another was applying for a tenure-track position and is also a single mom. For Julie, collaborative work is helpful because it builds in accountability; the same applies to CFPs.

Part of the reason why I think l've been struggling with the collaborative projects that I have is that these are projects driven by us without an acceptance or deadline from somebody else. If I know l've gotta turn something in to a journal by March, l'll start writing, but if it's just me and my friends playing around with an idea, well, that can always wait. If I'm going to work on a journal article by myself, I might let that rot for a while because nobody else is looking for it from me; it hasn't been accepted by anybody. It's just one of those things I float into the universe. What I like about book chapters instead is that I have accountability to my editors. They've got hard deadlines. I give them a proposal and they either accept it or reject it. That makes for a more structured work environment for me.

Unfortunately, the value of collaborative work is still contested in composition and rhetoric, yet we see from Julie how important collaboration can be for academic publications depending on your context (Daniel and Sura). The privileging of single-authored texts is evidenced in graduate school, where students are encouraged and expected to write single-authored research papers and dissertations, and then continues into faculty positions where, as Kristine Blair explains, "The emphasis is still on the single-authored monograph and what that has to look like and who has to publish it" (qtd. in Tulley 143). Privileging single-authored texts creates an unequal environment for academics, one in which individuals with particular material circumstances and embodied experiences are more likely to be rewarded and recognized for their work than others. Recognizing that collaboratively authored articles, books, and other academic scholarship require a unique set of skills and also create space for those who may be excluded when publication opportunities are limited to single-authored texts creates space for voices that may have been marginalized by traditional publishing standards, expectations, and norms. Julie's lack of academic publishing is not due to a lack of motivation or interest.

I have more things to work on than I have time to do them. l'd like to do something with the dissertation, either chopping it up or figuring out something to do with it. I've got some calls for book chapters that I'm interested in, and I've also got a couple of things that some colleagues of mine and I have been thinking about doing, edited collections, as well.
None of those projects are off the ground, but they're all things that kind of keep churning in the back of my head when I think about what I want to do.

Julie's story illustrates how someone can have the skills of a productive scholarly writer-organization, scheduling, and careful planning-yet still not complete what she refers to as "academic writing," the kind that often gains recognition and praise in composition and rhetoric. Being a single mom at a community college shapes what Julie can do, how she does it, and why she chooses to do it (or not). Her experiences push against traditional ideas of what constitutes writing productivity, particularly as it relates to research.

Through Julie we see the importance of paying attention to and valuing the kind of composition work that occurs outside publications. Julie's experience also provides insight into how a single parent at a community college completes composition work-two areas Tulley asserts need greater research (152-53). When we consider the writing process, we must consider not only time, space, and material resources but also people and how they can create affordances and/or constraints for writing.

\section{DANIELLE'S STORY}

One thing that was continually evident during the conversations I had with Danielle was the love she has for her son. She shared with me how she supported him after his first heartbreak, ensured he got to and from soccer practice, and had comforting conversations with him when he would call her from summer school. Danielle made clear, even though she didn't need to, that her son is her top priority: "At the end of the day his needs for me to be his mom outweigh any- and everything." From the beginning of Danielle's college experience, it has been just the two of them. She's currently working on her bachelor's degree part time, living with a brain injury, and also working full time as a paralegal; her son has ADHD. Her experience as a single-mom undergraduate "has been difficult, stressful, exhausting, frustrating, tense, but it has also been an outlet." Recently, Danielle took an introductory writing class online, which she found especially helpful to her as a single mom because "the online part-time option allows [her] to spend time as a mom and do work when [her] son is sleeping or after he is taken care of."

When Danielle started the introductory writing course, she was really upset about having to take the class because as a paralegal she has a fair amount of professional writing experience. She knew how to write independently, how to advocate for a change in writing style when she didn't like the way it sounded, and how to communicate with a range of people in the judicial system.

I write on a day-to-day level to very important peoplecorrespondence to judges, courts both federal and civil, 
attorneys, physicians-drafting subpoenas, pleadings, discovery, motions. I took a paralegal course to learn how to do the kind of writing I do for my job. When I started doing paralegal writing, I was like, "This sounds like you're a caveman. This sounds awful." I had to change the way I was writing to make it sound like caveman talk, so I asked at the firm, "Can I just make this sound a little bit better? Because I don't want to sound like a caveman anymore." The attorney gave me free rein to do what I wanted. He was super lenient because I think he just didn't want to do it, and then realized I'm actually pretty good at it.

In the writing I do at work, there have been times where I was given something and expected to produce a document with little to no direction or planning. Sometimes, l'll meet with a group of attorneys to discuss what needed to be done. For example, I recently met with three attorneys to discuss a legal process. I gathered and produced documents for review and then went back to make corrections. There are some legal writings I do without seeking feedback, and it would be rather cumbersome to do so. In my writing class, the primary differences between workshopping and my writing for work is in the context, as you cannot compare meeting with legal professionals to meeting with your academic peers because their thought processes are on different levels.

In the writing class, we did visual analysis and reflection, and I learned a lot of different things, like blog writing, which I would not know how to do on my own. I didn't like it at first, I hated it, but once I finally got the grasp of blog writing, and what it was to draw people in, then I was able to pull it all together. It was a lot of work going into this thing. I'm proud of what I created, and I think it looks pretty cool.

Danielle's experience at work and in her writing course show traditional ideas of transfer-how the writing she does for work has prepared and influenced the writing she does for school. Even though she wished her professional writing had been given greater consideration when determining her writing requirement (she told me that she felt the curriculum needed more flexibility, that it was "set for a traditional student" and "very traditional in what it requires"), she still made the most of her writing class and recognized the way context shapes writing situations, particularly workshop conversations. Understanding the role of context in writing is something Linda Adler-Kassner, Irene Clark, Liane Robertson, Kara Taczak, and Kathleen Blake Yancey point to as a "threshold concept" in transfer research. As a result of Danielle's introductory writing course and the writing she does professionally, she has a strong understanding of a foundational epistemology in academic writing. To put it another way, she recognizes that even though she may be engaged in a task work and school have in common-workshopping writing - the context shapes the way the workshop and her writing develop (Adler-Kassner et al. 25).

Danielle's experience also reflects the role her prior knowledge plays. We can see how her knowledge in one activity systemwork-influences her composing in another-school. Danielle is bringing into the writing classroom a wealth of composition knowledge from the various contexts she composes in.

In addition to writing for work and school, I also do a lot of written communication as far as email discussions between my child's school, the special education director, guidance counselor, and school-assigned social worker. While everything I compose at work allows me to think about my intended delivery and what I am trying to convey to the read$\mathrm{er}$, it is my life experiences and being a single mom which allows me to put so much emotion behind the words I write.

Danielle's description of working across different systems is reflective of David Russell's activity theory, which shows how writing is shaped not just by tools and people but also by events (508). His focus on "the ways writing links school and society" makes activity theory a helpful lens for looking at Danielle's composition practice (509). More specifically, Danielle's story illustrates Russell's concept of "activity systems" 4 in that it shows how various systems - work, school, and family — can interact (510). Whether it is for her writing class, her job, or her son's school, Danielle recognizes the importance of audience and the people on the other side of the page or screen. We see this awareness in how she identifies the specific people she is writing to, as well as how she emphasizes what it meant to "draw people in" to her blog for her writing class. Her sense of audience awareness and purpose is shaped by her paralegal and single mom writing experiences, yet she felt as though this type of writing experience was not valued in the composition classroom. When any student enters a composition class, it's important to make space for the knowledge they bring with them. For a single mom whose time is limited, this space is especially important.

While she identifies her professional experience as the facet that "allows [her] to think about [her] intended delivery," it is her life experience as a single mom that allows her to put a great deal of emotion behind her work. How might we account for this embodied knowledge students carry with them and bring into our composition classrooms? By acknowledging how her single-mom identity is an asset to her writing, Danielle is challenging traditional ideas that often stigmatize single moms and perpetuate a culture in which

3 Adler-Kassner et al. describe the five threshold concepts as "ideas that are most important for writing in post-secondary institutions," in part because they allow writers to "distinguish one community of practice from another" (18-19).

4 Informed by Vygotsky's "cultural-historical activity theory," as well as "Bazerman's genre systems theory," Russell defines an activity system as "any ongoing, object-directed, historically conditioned, dialectically structured, tool-mediated interaction" $(508,510)$. 
many single moms feel they need to remain silent about this part of themselves.

The connections between Danielle's single-mom identity and her writing are not only apparent in her composition process but also in her relationship with her son. When Danielle's son plagiarized, she used the writing she completed for her class to discuss plagiarism with him.

He had to write a story, and he had his ideas, and he started writing this paragraph, but his teacher said, "It's very unique. It's really good, but you just have a little bit of grammar things to fix here and there," so I gave him my computer thinking he could just type out stuff. Well, he decided to go online, find a story, and then copied and pasted it and said, "This is mine." The teacher gave him multiple times to come clean because she knew it wasn't his. His teacher ended up calling me and saying that he's not going to get written up, but he's getting no points for the entire project. I knew I needed to talk to my son about what happened, but before I did, I had to figure out how to approach the conversation. I don't like to come at him without a lesson to be learned because I feel that's how you learn. You learn through lessons. You learn through your mistakes. I ended up going through my project on my blog and I had him read it, and I showed him, here are all the steps. It was like step 1 through 6 . We had to keep revising over and over and over again. I showed him all the papers that I had scribbled on and written on and crumpled up and threw out-all of that. I took pictures of all of this, so that I could actually document it for a later project on my blog. With my brain injury, I have short-term memory loss, so documentation helps me remember all of the things I want to write about. Like sometimes, when I'm driving, I'll make voice memos on my phone so that I don't forget my ideas. The project I shared with my son was about a trip we had taken with other people, people who I saw as my community. My son read it, and he really liked it, and I said to him, "You know, l'd be really upset if somebody stole my work and said it was theirs," and we got into a discussion about stealing and why it's not right. When I showed him all those pictures I collaged, because it took me forever to get to my final product, I said, "Look at how hard I worked. I worked my butt off. This is many, many, many weeks of work, and for somebody to say that it was theirs, that would break my heart, that means my work was worthless." I asked him, "Why do you think that it was okay to take somebody else's work?"

\section{"Because mine didn't sound good."}

"The teacher said yours sounded pretty good. It sounded great, actually," I told him.

"Well, I just wanted it to be the best."
His self-esteem is very, very low. It always has been, ever since maybe first grade, and this is where it comes in. You keep going year after year and without any type of confidence boost, it's hard. Telling these kids that they're not good enough, they're going to do whatever it takes to be good enough, and if that means lying and cheating, they're gonna do it. It's not right. I'm hoping that doesn't happen again, but I get why it did.

Through Danielle's story, we see how the work she did in her introductory writing class became an asset to her in her personal life when she needed to teach her son about plagiarism. As instructors, we might not anticipate that students will use the writing in our classes in the way Danielle used hers-a tool for fostering empathy to teach a lesson.

Just as Danielle pays great attention to her audience in composing, she used her writing process to help her son consider the person on the other side of the page, the author. Research in rhetoric and composition has described strategies for plagiarism avoidance (Hartwig 2015; "Discouraging Plagiarism" 2020), as well as shown how faculty are trained to prevent plagiarism by learning how and when to "react (often in the form of judicial processes and procedures)" (Serviss 555). Danielle's identity as a single mom allowed her to approach teaching plagiarism to her son in another way, empathy with the original author. Such an approach resembles Sandra Jamieson's call to ask why students fail to "engage with ideas and formulate their own responses" instead of focusing on the student's "guilt" (106). Like Jamieson, Danielle saw her son's behavior as "an opportunity for pedagogical intervention, regardless of whether the plagiarism was intentional or 'accidental'" (106). In Danielle's experience, we see what can happen when plagiarism is seen as a pedagogical opportunity rather than a judicial one. Danielle's story shows the intertwined nature of the composition classroom, professional life, and lived experience. Her story touches on very familiar and well-researched aspects in composition-transfer and plagiarism in particular-yet her approach is not directly informed by them but instead by her lived experience. How might we account for the transfer of embodied knowledge in composition classes? If we approached teaching about plagiarism through empathy, what might happen? Danielle gives us a glimpse into what composition can look like when it incorporates a single-mom perspective.

\section{CONCLUSION}

Prior to my divorce, I had substantial flexibility with my writing time; I wrote when I wanted to rather than when I had to. While I planned what I was going to write, I had to do less around planning when I actually wrote, and I could easily block out large chunks of time to get my writing done. Now, I have found I have to plan for when I won't be writing, for when my daughter will want to bake cupcakes or build a fort or walk around outside looking for "aminal" tracks in 
the snow. I write as much as I can manage when I have the time in order to build a writing cushion for the time l'll spend with her and no writing gets done because, like Kate Vieira, that time with my daughter is precious; it's a chance for us to "irritate the bejeesus out of each other." The composition process of a single mom is one of improvisation, of finding a way to make space for composition work, and of pushing the boundaries of what a composing process looks like and what it means.

Being a single mom means you often must figure things out as they come, which is reflected in the ways Tricia, Julie, and Danielle compose. Tricia had already developed certain ways of composing, of engaging in academic work, because of her single-mom identity. When she sustained a head injury, leaving her unable to type or hand write, she found another way-painting. Julie is highly skilled at organization, time management, and prioritizing tasks because, as a single mom, she is managing her own demanding schedule, as well as the schedules of both her children and their family pets. These skills were part of the reason she was able to finish her dissertation, but they're also part of the reason her academic writing has currently been on hold. When academic writing was no longer a requirement, she was able to reallocate it on her priority list while also accepting and understanding that decision. Danielle's single-mom identity has given her a combination of embodied and rhetorical knowledge that is reflected in the relationships among her professional writing, her academic writing and her personal life. Her sense of audience awareness and context informs how she approaches interpersonal actions in workshops with peers, meetings with attorneys, and conversations with her son.

When we look at the composing processes of individuals, we can see how, where, and when they compose, as well as what habits and skills they have developed to get their writing done. Such information can inform how we understand, make sense of, and value different types of composition, and in turn how we teach, mentor, and support students, colleagues, and peers. The composition practices of single moms push us to think about what is possible when we are open to what can happen with composition practice and production. Even though our understanding of the writing process of those with marginalized identities is limited, these stories make clear the wealth of what can be learned by making space for what still lies in the interstices.

\section{Works Cited}

Adler-Kassner, et. al. "Assembling Knowledge: The Role of Threshold Concepts in Facilitating Transfer." Critical Transitions: Writing and the Question of Transfer, edited by Chris M. Anson and Jessie L. Moore, UP of Colorado, 2016, pp. 17-47. https://doi.org/10.37514/ PER-B.2016.0797.2.01
Daniel, Julia, and Thomas Sura. "From 'I Still Can't Work with You' to 'Let's Work Together': Creating a Rhetoric of Collaboration that Supports Professors." MLA Profession, September 2018, https://profession.mla.org/from-i-stillcant-workwith-you-to-lets-work-together-creating-arhetoric-of-collaboration-that-supportsprofessors.

"Discouraging Plagiarism." Writing@CSU, 2020, https://writing. colostate.edu/guides/teaching/fys/plagiarism.cfm.

Duquaine-Watson, Jillian M. Mothering by Degrees: Single Mothers and the Pursuit of Postsecondary Education. Rutgers UP, 2017.

Hartwig, David. "Student Plagiarism and First-Year Composition: A Study." Teaching English in the Two Year College, vol. 43, no. 1,2015 , pp. 38-56.

Jamieson, Sandra. 'Shouldn't Our Expectations of Students' and Academics' Intertextuality Practices Differ?" Student Plagiarism in Higher Education, edited by Diane Pecorari and Philip Shaw, Routledge Research in Higher Education Series, Taylor \& Francis, 2018, pp. 104-122.

Latina Feminist Group. Telling to Live: Latina Feminist Testimonios. Duke UP, 2001.

Lillis, Theresa. Student Writing: Access, Regulation, Desire. Routledge, 2001.

"America's Families and Living Arrangements: 2019." United States Census Bureau, 2019, table FG5. https://www. census.gov/data/tables/2019/demo/families/cps-2019.html.

Pérez, Emma. The Decolonial Imaginary: Writing Chicanas into History. Indiana UP, 1999.

Prior, Paul, and Jody Shipka. "Chronotopic Lamination: Tracing Contours of Literate Activity." Writing Selves, Writing Society, edited by Charles Bazerman and David R. Russel. WAC Clearinghouse, 2002, pp. 180-239.

Rogers, Paul. "The Contributions of North American Longitudinal Studies of Writing in Higher Education to Our Understanding of Writing Development." Traditions of Writing Research, edited by Charles Bazerman, et. al., Routledge, 2009, pp. 365-78.

Russell, David. "Rethinking Genre in School and Society: An Activity Theory Analysis." Written Communication, vol. 14, no. 4, 1997, pp. 504-54.

Serviss, Tricia. "Creating Faculty Development Programming to Prevent Plagiarism: Three Approaches." Handbook of Academic Integrity, edited by Tracey Bretag, Springer, 2016, pp. 551-67.

Shipka, Jody. "Introduction: Multimodality and Communicative Practice." Toward a Composition Made Whole. University of Pittsburgh Press, 2011, pp. 1-17.

Sidel, Ruth. Unsung Heroines: Single Mothers and the American Dream. U of California P, 2006.

Takayoshi, Pamela. "Writing in Social Worlds: An Argument for Researching Composing Processes." College Composition and Communication, vol. 69, no. 4, 2018, pp. 550-80. 
Townsend, Barbara K., and Vicki J. Rosser. "The Extent and Nature of Scholarly Activities among Community College Faculty." Community College Journal of Research and Practice, vol. 33, no. 9, 2009, pp. 669-81.

Tulley, Christine. How Writing Faculty Write: Strategies for Process, Product, and Productivity. UP of Colorado, 2018.

Vieira, Kate. "Interview with Kate Vieira." Arts + Literature Laboratory, 2018, https://artlitlab.org/reviews/interviewwith-kate-vieira.

\section{Acknowledgements}

Thank you to the single mom participants for trusting me with your stories; this work is built from your voices and wouldn't exist without you. I am so grateful to the anonymous reviewers, both single parents, whose time and feedback helped strengthen this work. I also greatly appreciate the editors of WCC for their generosity, support, and patience. The work of Jessica and Gabby Spruill made this work possible - thank you for providing the kind of care for Livy that gave me pockets of uninterrupted writing time. Finally, thank you to my sister, Becky, whose invitation to dog sit came at just the right time to draft this article. 